\title{
Entre resistências, avanços e retrocessos: um panorama sócio-histórico das comunidades quilombolas no Brasil e na região do Cariri Cearense
}

\author{
Between resistance, advances and setbacks: a socio-historic overview of quilombola communities in \\ Brazil and in the Cariri region of Cearense \\ Entre resistencias, avances y retrocesos: una visión socio-histórica de las comunidades quilombola \\ en Brasil y en la región cariri de cearense
}

Tayronne de Almeida Rodrigues ORCID: https://orcid.org/0000-0001-9378-1456 Universidade Federal do Cariri, Brasil E-mail: tayronnealmeid@gmail.com

Francisca Laudeci Martins Souza ORCID: https://orcid.org/0000-0003-4211-3233 Universidade Regional do Cariri, Brasil E-mail: laudecimartins@gmail.com

Zuleide Fernandes de Queiroz ORCID: https://orcid.org/0000-0003-3174-4750 Universidade Regional do Cariri, Brasil E-mail: zuleidefqueiroz@gmail.com

Cicera Nunes

ORCID: https://orcid.org/0000-0002-6352-8991 Universidade Regional do Cariri, Brasil E-mail: cicera.nunes@urca.br

\begin{abstract}
Resumo
O presente artigo objetiva discutir o conceito de quilombo sob uma perspectiva histórica e teórica valendo-se de uma revisão bibliográfica sobre o tema. Adota como objeto de investigação a delimitação do conceito de comunidade quilombola a partir de suas origens em território africano, sua inserção na realidade brasileira e, por fim, com enfoque no estado do Ceará e, mais especificamente, na região do Cariri cearense, abordando uma comunidade quilombola específica, o Sítio Arruda. Constatamos que, em sua constituição africana, o quilombo tratou-se de uma instituição social revolucionária. No entanto, os quilombos no Brasil foram se distanciando do modelo africano, construindo trajetórias próprias. O conceito de quilombo (kilombo) passou a ser sinônimo de povo negro e deve ser compreendido como um marco de resistência e organização. A partir da década de 1970 também ocorre o fortalecimento dos movimentos sociais negros. Tal fenômeno, somado às mudanças advindas da Constituição de 1988, terá como resultado o reconhecimento do direito ao território às comunidades negras. No Estado do Ceará persistiu a falsa ideia de ausência dos negros. No entanto, durante a década de 1980, iniciou-se um processo de "descoberta" de agrupamentos negros evidenciando a forte presença quilombola no Estado e a constituição do movimento negro. Finalmente, a partir da constituição identitária da comunidade quilombola Sítio Arruda vemos que as migrações para a região do Cariri cearense devem ser consideradas como um fator importante na formação e consolidação do contexto quilombola local.
\end{abstract}

Palavras-chave: Comunidades quilombolas; Ceará; Região do Cariri; Quilombo sítio Arruda.

\begin{abstract}
This article aims to discuss or conceive the quilombo in a historical and theoretical perspective through a literature review on or subject. As an object of investigation, the delimitation of the quilombola community council is linked since its origin in the African territory, its insertion in the Brazilian reality and, in this sense, with a non-state approach to Ceará and, more specifically, to the region. do Cariri Cearense, aimed at a specific quilombola community, or Sítio Arruda. We note that in its African constitution, or quilombo, it is a revolutionary social institution. However, the quilombos in Brazil were distancing themselves from the African model, building their own costumes. The concept of quilombo became synonymous with black people and should be understood as a framework for resistance and organization. From the 1970s onwards, two black social movements also developed or strengthened. This phenomenon, caused by changes arising from the 1988 Constitution, will be the result or restoration of the territory or territory of black communities. In the State of Ceará, a false idea of the absence of two blacks persisted. However, during the 1980s, a process of "discovery" of black groups began, evidencing the quilombola presence and not the State and the constitution of the black movement. Finally, from the constitution of
\end{abstract}


the identity of the quilombola community of Sítio Arruda, we see that migration to the Cariri region of Ceará should be considered an important factor in the formation and consolidation of the local quilombola context.

Keywords: Quilombola communities; Ceará; Cariri region; Quilombo sítio Arruda.

\begin{abstract}
Resumen
Este artículo tiene como objetivo discutir o concebir el quilombo en una perspectiva histórica y teórica a través de una revisión de la literatura sobre o tema. Como objeto de investigación, la delimitación del consejo comunal quilombola está vinculada desde su origen en el territorio africano, su inserción en la realidad brasileña y, en este sentido, con un acercamiento no estatal a Ceará y, más específicamente, a la región. do Cariri Cearense, dirigido a una comunidad quilombola específica, o Sítio Arruda. Observamos que en su constitución africana, o quilombo, es una institución social revolucionaria. Sin embargo, los quilombos en Brasil se fueron distanciando del modelo africano, construyendo sus propios trajes. El concepto de quilombo se convirtió en sinónimo de gente negra y debe entenderse como un marco de resistencia y organización. A partir de la década de 1970, también se desarrollaron o fortalecieron dos movimientos sociales negros. Este fenómeno, provocado por los cambios derivados de la Constitución de 1988, será el resultado de la restauración del territorio o territorio de las comunidades negras. En el estado de Ceará persistía una falsa idea de la ausencia de dos negros. Sin embargo, durante la década de 1980 se inició un proceso de "descubrimiento" de grupos negros, evidenciando la presencia quilombola y no el Estado y la constitución del movimiento negro. Finalmente, a partir de la constitución de la identidad de la comunidad quilombola de Sítio Arruda, vemos que la migración a la región Cariri de Ceará debe ser considerada un factor importante en la formación y consolidación del contexto quilombola local.
\end{abstract}

Palabras clave: Comunidades quilombolas; Ceará; Región Cariri; Quilombo sítio Arruda.

\title{
1. Introdução
}

No atual cenário da política brasileira, muitos têm sido os desafios para as comunidades quilombolas. Já não bastassem as dificuldades inerentes à pandemia de COVID-19 em curso, retrocessos com relação aos direitos dos povos e comunidades tradicionais têm sido colocadas na ordem do dia da atual gestão governamental. Conforme argumentam Corrêa $e t$ al. (2020), o atual projeto do governo federal tem privilegiado o modelo latifundiário e exportador do agronegócio, o que pressiona os territórios ancestrais das comunidades quilombolas colocando-os, muitas vezes, como verdadeiros inimigos do desenvolvimento econômico do país.

Uma das faces dessa política de retrocessos pode ser verificada a partir do esvaziamento e aparelhamento de instituições públicas que possuem competências relacionadas ao cumprimento dos dispositivos constitucionais que protegem os direitos dos povos e comunidades tradicionais. Nesse sentido, não é surpreendente, por exemplo, o fato da Fundação Cultural Palmares, no ano de 2019, ter titulado parcialmente apenas duas comunidades quilombolas (Corrêa et al., 2020) ${ }^{1}$.

De uma maneira geral, ao longo deste artigo iremos abordar o conceito de quilombo a partir de suas transformações sócio-históricas. Inicialmente, fizemos uma breve imersão pela origem africana do quilombo (kilombo) a partir dos estudos de Nascimento (2018 [1985]) e sua compreensão acerca da relação entre a formação dos quilombos no Brasil e suas origens territoriais e de composição étnica em Angola. Na sequência, retomamos as conotações que a instituição quilombo recebeu no período colonial e imperial no Brasil e, também a partir de Nascimento (idem), veremos que, no final do século XIX emerge um significado de instrumento ideológico atribuído ao conceito de kilombo, caracterização ideológica que adentra o século XX. A fim de complementar a visão dessa autora, retomamos os argumentos de Moura (2021) de que a presença dos quilombos ocorreu durante todo o período escravista e em todo o território nacional. Na visão de Moura (idem), essa continuidade histórica somada à dilatação geográfica acabou por configurar o quilombo como a unidade básica de resistência do escravizado.

\footnotetext{
${ }^{1}$ As etapas que envolvem o processo de certificação e titulação territorial das comunidades quilombolas no país serão tratadas no tópico 3.1, intitulado "Comunidades Quilombolas no Brasil".
} 
Já a partir de Marques e Gomes (2013) vemos que a partir da década de 1970 ocorre, no Brasil, o fortalecimento dos movimentos sociais negros, fenômeno que se somou à promulgação da Constituição de 1988 com o reconhecimento do direito ao território às comunidades negras. Também afirmamos que o atual conceito de quilombo difere de forma substancial do que representava durante o regime escravocrata e posteriormente à abolição da escravidão, além da formulação de uma crítica à denominação remanescentes de quilombos.

Após esse panorama sócio-histórico abordarmos a presença da população negra no Estado do Ceará, com o interesse de argumentar pela importância da contribuição dessa população na formação sociocultural desse Estado. Já os dois últimos subtópicos tratam, especificamente, da região do Cariri cearense retomando o processo de formação territorial dessa região com enfoque nas comunidades quilombolas para, finalmente, ponderarmos sobre a constituição identitária do Sítio Arruda.

\section{Metodologia}

Os retrocessos atuais na garantia dos direitos das comunidades quilombolas só podem ser efetivamente compreendidos quando temos ciência dos aspectos estruturais vinculados ao processo sócio-histórico que envolve o conceito de quilombo no Brasil. É por isso que neste artigo será traçado um panorama de tal conceito valendo-se de uma revisão bibliográfica sobre o tema. "A principal vantagem da pesquisa bibliográfica reside no fato de permitir ao investigador a cobertura de uma gama de fenômenos muito mais ampla do que aquela que poderia pesquisar diretamente” (Gil, 2017, p. 45). Para tal, propomos um recorte delimitando o conceito de quilombo desde sua constituição em território africano (Nascimento, 2018 [1985]), sua inserção na realidade brasileira (Nascimento, idem; Marques e Gomes, 2013; Moura, 2021; Querino, 2018) e, por fim, com enfoque no estado do Ceará (Ratts, 1998; Silva, 2017), mais especificamente na região do Cariri cearense (Tavarres, 2020), abordando uma comunidade quilombola específica, o Sítio Arruda.

\section{A Constituição Africana do Quilombo (Kilombo)}

Ao caracterizar o quilombo (kilombo) como uma instituição africana, de origem angolana e inserido na história da pré-diáspora, Nascimento (2018 [1985]) explica que dentre os interesses dos portugueses na colonização de Angola estavam a busca por terras para se fixarem e, principalmente, a busca por minérios. Com a frustração relativa aos minérios, o empreendimento colonial passou a se dedicar ao lucrativo tráfico escravista. Uma região ao sul de Angola, território da etnia Mbundo, torna-se, então, conhecida como uma "zona de caça" - trata-se do reino de Ndongo, cujo rei se considerava descendente de Ngola, o herói civilizador do povo Mbundo em que Angola seria uma variação do nome Ngola.

De acordo com Nascimento (2018 [1985]), concomitante à invasão portuguesa ocorriam conflitos entre diversas etnias no continente africano. É nesse contexto de conflitos interétnicos que se destaca a atuação do povo Imbangala ou Jagas caçadores vindos do Leste que a partir de 1560 iniciaram um processo de invasão de territórios. Ao final do século XVI os Imbangala ou Jagas, que dominaram Angola, uniram-se aos Mbundo contra a penetração portuguesa.

Os Imbangala ou Jagas possuíam uma organização social baseada no nomadismo e amplamente aberta aos estrangeiros. Essa forma de organização social, que cortava transversalmente as rígidas estruturas de linhagem e clãs, tão característica das etnias africanas, passou a definir o próprio conceito de kilombo enquanto uma instituição social revolucionária. No mais, os Imbangala ou Jagas iniciavam os jovens estrangeiros de várias linhagens para sua incorporação nessa sociedade guerreira. A iniciação ritual envolvia a prática da circuncisão e os indivíduos iniciados também eram chamados de kilombo, assim como a própria casa sagrada onde ocorria o ritual de iniciação. Por último, e ainda com relação ao nome kilombo, Nascimento (2018 [1985]) afirma que os Imbangala, que passariam a praticar o comércio negreiro com os portugueses, chamavam o grupo escravizado de kilombo. 
Qual a relação entre a formação de um quilombo no Brasil e suas origens territoriais e de composição étnica em Angola? Para Nascimento (idem), a resposta a essa pergunta seria muito dificultada ante à inexistência de documentação histórica suficiente para comprovar que os integrantes dos quilombos brasileiros seriam descendentes diretos dos envolvidos no processo acima descrito ocorrido na África. No entanto, pelo menos um caso de relação direta seria possível atestar, como veremos na próxima seção.

\subsection{Comunidades quilombolas no Brasil}

Ao tratar das conotações que a instituição quilombo recebeu no período colonial e imperial no Brasil, Nascimento (2018 [1985]) indica que, no nordeste brasileiro, tornaram-se cada vez mais frequentes as investidas militares contra os núcleos de população negra livre do domínio colonial, como a República de Palmares, que resistiu até o ano de 1695.

Nascimento (idem) observa que durante o século XVII (1601-1700) houve um aumento da resistência de outros quilombos no Brasil, e que o ocorrido em Palmares possui um paralelo com o processo histórico em curso no final do século XVI (1501-1600), em Angola. Para a autora, existe uma correlação concreta entre Palmares e o kilombo angolano. Uma das provas disso seria o próprio nome Angola-Janga - ou seja, território (Ngola) e etnia (Jaga) vinculados à instituição kilombo atribuído ao quilombo dos Palmares.

Nascimento (idem) também pondera que os quilombos no Brasil foram se distanciando do modelo africano, construindo uma trajetória a partir de suas próprias necessidades. Ao longo do período colonial, o quilombo no Brasil teria se caracterizado pela formação de grandes Estados, como o da Comarca do Rio das Mortes, em Minas Gerais, que foi desmembrado em 1750. Isso contribui para que se evidenciasse a fragilidade colonial marcada pela fuga em que o quilombo representa um "perigo negro", justificando as guerras ocorridas na Bahia e no Maranhão. Aos quilombos de grande porte que se encontravam nas periferias dos centros urbanos somam-se um arcabouço ideológico em que a fuga implica na própria reação ao colonialismo.

Com a passagem da colônia para império, durante o século XIX, os levantes negros passaram a ter um caráter abolicionista, e ao final desse século emergiu um significado de instrumento ideológico atribuído ao conceito de kilombo como reação às formas de opressão. Ou seja, mais que instituição, kilombo passaria a ser redefinido como um símbolo de resistência . Tal caracterização ideológica adentra o século XX alimentando os anseios de liberdade como consciência nacional. Conforme argumenta Nascimento (idem), durante a década de 1970, o quilombo tornou-se um código de reação ao colonialismo cultural ao reafirmar a herança africana e buscar um modelo brasileiro de fortalecimento da identidade étnica. Para Nascimento (2018 [1985]), o conceito de quilombo (kilombo) passou a ser sinônimo de povo negro e deve ser compreendido como um movimento de âmbito social e político que representou um marco de resistência e organização.

Outro autor fundamental sobre a presença dos quilombos no Brasil é Clóvis Moura. Em sua obra "Quilombos: resistência ao escravismo", Moura (2021) argumenta que os quilombos existiram tanto no Brasil quanto em outras partes da América onde ocorreu o escravismo moderno, marcado pelas condições desumanas às quais eram submetidas as populações negras. O autor discorre que no Brasil essas comunidades de ex-escravos estavam organizadas de diversas formas e tinham proporções e duração muito diferentes. O autor também pondera que embora o aquilombamento não tivesse um novo projeto de ordenação social com capacidade para substituir o escravismo, por outro lado, havia potencial e dinamismo suficientes para provocar permanentes crises em sua estrutura.

Em linhas gerais, Moura (2021) argumenta que os quilombos contribuíram para a deterioração das relações entre senhores e escravos, não se resumindo à manifestação esporádica de pequenos grupos de escravizados marginais que não possuíam consciência social. Pelo contrário, o autor argumenta que se tratou de um movimento que agiu de forma permanente sobre o centro de um sistema nacional. 
É interessante também retomar a classificação retomada por Moura (2021) referente à organização econômica dos quilombos no Brasil. Como pondera o autor, havia diversas formas de organização da produção, dentre as quais os quilombos: I - os agrícolas, presentes em todo o território nacional; II- os extrativistas, predominantes na região amazônica; III - os mercantis, também presentes na região amazônica e que adquiriam dos povos indígenas as drogas do sertão para comercializálas com os comerciantes; IV - os mineradores, predominantes em Minas Gerais, Goiás, Mato Grosso e Bahia; V - os pastoris, no Rio Grande do Sul, dedicados à criação de gados; VI - os de serviços, em que os quilombolas se dirigiam aos centros urbanos para trabalhar e VII - os predatórios, existentes em todo o território e que se dedicavam aos saques praticados contra os brancos.

Moura (2021) argumenta que independentemente do tipo de atividade econômica desenvolvida pelo quilombo, ocorria uma economia de abundância. Isso porque, na visão do autor, por não se dedicarem à monocultura das plantations, os quilombos exploravam os recursos naturais regionais a partir de uma agricultura do tipo policultora e comunitária. Dessa forma, além de satisfazerem as necessidades dos quilombolas também havia a produção de um excedente comerciável.

Outra característica dos quilombos no Brasil, destacada por Moura (2021) diz respeito ao binômio economia-defesa. Sujeitos às invasões periódicas, os quilombos organizaram uma estrutura de poder centralizada capaz de defendê-los. Dessa forma, além de manter em atividade permanente grande parte da mão de obra ativa da comunidade na agricultura, também precisavam manter um contingente de defesa militar permanente. Por tudo isso, a obediência incondicional ao chefe escolhido pela comunidade era uma constante.

Como temos visto, ainda que a presença dos Quilombos seja contínua ao longo da história do Brasil, de fato, conforme demonstram Marques e Gomes (2013), é somente a partir da década de 1970 que passa a ocorrer o fortalecimento dos movimentos sociais negros e a emergência de lutas localizadas de comunidades negras rurais, como nos estados do Pará e do Maranhão. Tal fenômeno, somado às mudanças político-institucionais e administrativas advindas da Constituição de 1988 terá como resultado o reconhecimento do direito ao território às comunidades negras. Garantido na Carta Magna através do Artigo 68 do Ato das Disposições Constitucionais Transitórias (ADCT), lê-se: “Aos remanescentes das comunidades dos quilombos que estejam ocupando suas terras é reconhecida a propriedade definitiva, devendo o Estado emitir-lhes os títulos respectivos" (Brasil, 1988).

Ainda se tratando da Constituição Federal de 1988, temos os artigos 215 e 216:

Art. 215. O Estado garantirá a todos o pleno exercício dos direitos culturais e acesso às fontes da cultura nacional, e apoiará e incentivará a valorização e a difusão de manifestações culturais [...].

Art. 216. Constituem patrimônio cultural brasileiro os bens de natureza material e imaterial, tomados individualmente ou em conjunto, portadores de referência à identidade, à ação, à memória dos diferentes grupos formadores da sociedade brasileira, nos quais se incluem: I - as formas de expressão; II - os modos de criar, fazer e viver. (Constituição Federal, 1988).

De acordo com Marques e Gomes (2013), o direito ao território quilombola ao mobilizar o conceito de patrimônio cultural material e imaterial acaba por associar o reconhecimento identitário às dimensões vinculadas aos bens culturais de maneira mais ampliada. Outro importante avanço para a efetivação dos direitos territoriais das comunidades quilombolas foi a regulamentação para o procedimento de identificação, reconhecimento, delimitação, demarcação e titulação das terras ocupadas por remanescentes das comunidades de quilombos, definida pelo Decreto Presidencial 4.887, de 2003 (Brasil, 2003). Ainda de acordo com os autores, tais direitos territoriais tratam-se de avanços consideráveis ante o histórico direito repressivo que existiu durante o período colonial e imperial no Brasil e o descaso presente no período republicano.

No Brasil, o reconhecimento formal das comunidades quilombolas envolve a certificação pela Fundação Cultural Palmares (FCP), que analisa os pedidos das comunidades a partir de suas características históricas enquanto localidades 
ameaçadas e/ou vitimizadas de expulsão de seus territórios originalmente ocupados. No entanto, para que o processo leve à titulação do território um longo processo deve ser cumprido.

Após a FCP emitir o certificado de reconhecimento, ocorre o registro da comunidade quilombola no "Cadastro Geral dos Remanescentes de Quilombos da Fundação Cultural Palmares”. Na fase subsequente, entra em cena o Instituto Nacional de Colonização e Reforma Agrária (INCRA) para a abertura, caracterização da comunidade e produção do Relatório Técnico de Identificação e Delimitação (RTID).

Com a publicação do RTID, ocorre a consulta a órgãos e entidades envolvidas no processo e o julgamento das contestações e manifestações contrárias à titulação. Depois disso, é publicada a portaria do presidente do INCRA reconhecendo e declarando os limites das terras do território quilombola e, no caso de haver terceiros no território reconhecido como quilombola, ocorre a desapropriação ou anulação de títulos de posse viciados e reassentamento de posseiros. Finalmente, ocorre a demarcação física, outorga do título e registro em cartório. Conforme observam Marques e Gomes (2013), tal percurso pode ainda contar com a atuação de órgãos estaduais e, de uma maneira geral, é extremamente moroso e pode durar décadas.

É preciso também considerar que a luta da população negra pelo direito à territorialidade precede a Constituição de 1988. Ou seja, as formas de organização e resistência das diferentes modalidades de territorialização - os quilombos, as terras de preto, os mocambos - construíram uma longa história marcada por conflitos e lutas sociais que resultaram na garantia do direito constitucional (Marques e Gomes, 2013).

Outro ponto importante a ser considerado refere-se ao próprio significado dos chamados remanescentes de quilombo ou quilombolas. Conforme argumentam Marques e Gomes (2013), trata-se, sobretudo, de um fenômeno sociológico caracterizado pela indissociabilidade entre identidade e território em que processos sociais e políticos permitiram aos grupos uma autonomia vinculada a uma territorialidade específica cortada pelo vetor étnico no qual determinados grupos sociais buscam ser reconhecidos - em suma, diz respeito a uma afirmação étnica e política.

Marques e Gomes (2013) argumentam que os grupos quilombolas tratam-se, sobretudo, de grupos sociais que se articulam a partir de organizações sociais, religiosas, sindicais, políticas em busca do autorreconhecimento como um grupo específico que busca pelo direito à sua territorialidade. Esses grupos podem apresentar algumas ou todas das seguintes características, quais sejam: relações com a escravidão, rituais ou religiosidades compartilhadas, origem ou ancestrais em comum, relações de parentesco generalizado e uma ligação profunda com o seu território.

De acordo com Marques e Gomes (2013), o termo quilombo conforma um campo conceitual que possui uma longa história. Até meados da década de 1990 a Fundação Cultural Palmares (FCP) compreendia o quilombo a partir de suas qualidades culturais substantivas e por sua história de lutas passadas, assim como uma unidade guerreira e autossuficiente. Tais definições, no entanto, deixaram de satisfazer os anseios criados pelo dispositivo constitucional (ADCT 68) e passou-se a considerar a categoria remanescentes de quilombo como um autorreconhecimento por parte dos atores sociais envolvidos, conforme mostram as Figuras 1 e 2.

Importante destacar, conforme argumentam Marques e Gomes (idem), que o atual conceito de quilombo difere de forma substancial do que representava durante o regime escravocrata e posteriormente à abolição da escravidão. Pois se tratava, aos olhos das classes dominantes e dos instrumentos de repressão, de uma categoria vinculada à criminalidade, à marginalidade e ao banditismo. Tal definição só teria começado a ser transformada a partir da atuação de movimentos organizados pelos próprios quilombolas e com a Constituição de 1988 o termo quilombo passaria a representar, juridicamente, uma nova concepção.

Já o termo remanescentes de quilombo, de acordo com os argumentos de Marques e Gomes (2013), exprime um direito a ser reconhecido em suas especificidades. Nesse ponto, observam os autores que o art. 68 acaba por criar a categoria política e sociológica detentora do direito à propriedade definitiva das terras ocupadas. No entanto, os grupos étnicos sujeitos 
de direitos em questão não utilizavam a denominação remanescentes de quilombos - trata-se, então, de uma categoria analítica ligada a uma visão objetificadora e passadista do conceito de quilombo.

Figura 1 - Comunidades Quilombolas certificadas pela Fundação Cultural Palmares (FCP).

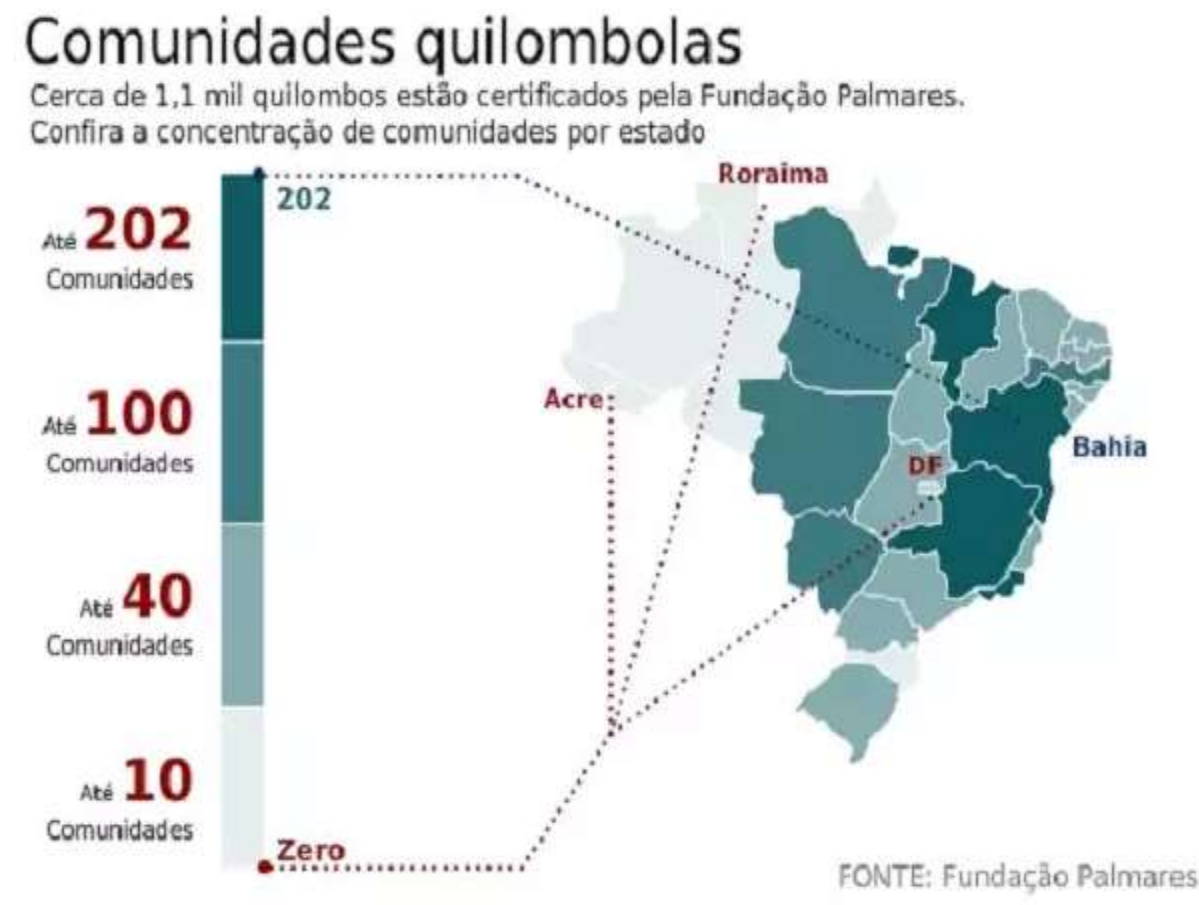

Fonte: Fundação Cultural Palmares (2017).

Figura 2 - Comunidades Quilombolas por Estado.

\section{Número de Comunidades Remanescentes de Quilombos por Estado}

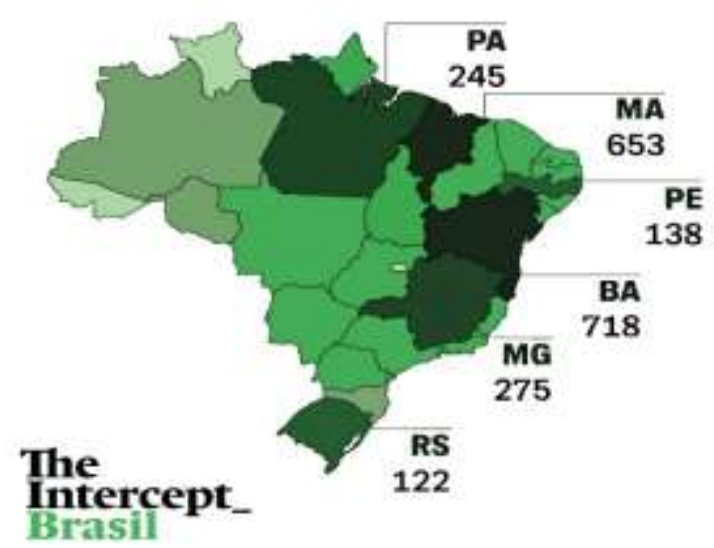

$\begin{array}{llll}\text { BA } 718 & \text { PB } & 38 \\ \text { MA } 653 & \text { PR } & 37 \\ \text { MG } 275 & \text { RJ } & 35 \\ \text { PA } 245 & \text { SE } & 35 \\ \text { PE } 138 & \text { GO } & 33 \\ \text { RS } 122 & \text { MS } & 22 \\ \text { PI } 86 & \text { RN } & 22 \\ \text { MT } 71 & \text { SC } & 13 \\ \text { AL } & 68 & \text { AM } & 8 \\ \text { SP } & 54 & \text { RO } & 8 \\ \text { CE } 46 & \text { AC } & 9 \\ \text { TO } 44 & \text { DF } & 0 \\ \text { AP } & 49 & \text { RR } & 0 \\ \text { ES } 38 & & \\ & & \end{array}$

Fonte: Fundação Cultural Palmares (2017).

Até aqui vimos que o conceito de quilombo passou por significativas mudanças desde sua constituição em território africano. De uma maneira geral, o processo histórico que envolveu os quilombos foi marcado pela invisibilidade, pela repressão e negação de direitos. Nesse sentido, os poucos avanços conquistados são muito recentes se comparados a uma história de 
longa duração marcada por violências de toda ordem. Por sua vez, e infelizmente, a história dos quilombos no estado do Ceará não é muito diferente da do restante do país. Como veremos a seguir, talvez um elemento ganhe destaque com relação à população negra cearense: o paradoxo entre uma província que primeiro libertou seus escravizados e a construção de um discurso dominante de negação de sua presença.

\subsection{Ceará: Território Negro}

Neste tópico, tratamos da presença da população negra no Estado do Ceará. Mais especificamente, interessa-nos sustentar a importância da contribuição dessa população na formação sociocultural do Ceará.

Conforme demonstra Silva (2017), o processo de ocupação do Ceará se desenvolveu a partir do século XVII por meio das chamadas frentes colonizadoras sertão-de-fora, controlada por pernambucanos vindos do litoral, e as frentes sertão-dedentro, controlada pelos baianos. Nesse contexto, a província de Pernambuco foi uma grande abastecedora da mão de obra escravizada de origem africana para o Ceará, situação que perdurou até o final do século XVIII.

Durante o século XIX, os cearenses passaram a controlar de maneira mais efetiva sua economia e houve, nesse período, tentativas de negociantes locais na importação de cativos oriundos da África. No entanto, os escravizados africanos continuaram chegando ao Ceará por intermédio do tráfico pernambucano. Também é no século XIX, conforme argumenta Silva (2017), que a até então economia baseada na criação bovina começa a se dinamizar com a produção do algodão. Isso contribuiu com a fixação da população sertaneja, pois grandes proprietários de terra e criadores de gado mantinham os produtores de algodão como agregados e parceiros em suas propriedades.

Silva (2017) observa que o couro de gado e a carne de charque - que se tornaram símbolos da cultura cearense - são produtos que pertencem a um legado africano, o que evidencia, na visão da autora, a presença da população negra no Ceará, cuja mão de obra escravizada foi utilizada nas mais diversas atividades econômicas. A economia voltada para o mercado interno tão presente no Ceará, ainda que não tenha se desenvolvido sob a presença dos grandes engenhos com o escravismo baseado no modelo da Casa Grande e Senzala, evidencia que a presença da mão de obra negra escravizada sempre foi muito significativa nesse Estado.

Nesse ponto relativo ao dinamismo da mão de obra negra escravizada é interessante retomar Querino (2018). O autor argumenta que a capacidade para a realização de atividades econômicas diversificadas é um elemento central da presença dos africanos escravizados no Brasil. O autor destaca que o modo de vida africano adaptado aos diversos ambientes somados aos conhecimentos trazidos da África foram fundamentais para o desenvolvimento inicial da Colônia e determinou o posterior desenvolvimento do país. Isso porque a mão de obra africana detinha desde o conhecimento sobre técnicas de caça à extração do sal e a mineração do ferro, do ouro, da prata e do diamante. Atividades como as de marinheiro, agricultor e mercador amplamente realizadas no continente africano fizeram com que o negro escravizado em solo brasileiro e cearense colocasse em prática um saber fazer fundamental para o progresso econômico.

Voltando ao contexto especificamente cearense, Silva (2017) também argumenta que, durante o século XIX, ocorreu um crescimento da escravidão africana e de afrodescendentes concomitante a um aumento da presença de negros livres em busca dos sertões cearenses oriundos do litoral e de outras províncias. A partir da segunda metade do século XIX, o Estado do Ceará também se consolida como um centro exportador e lugar de saída de mão de obra escravizada para a região sudeste, em especial para a zona canavieira e cafeicultora em São Paulo e, em menor escala, para o Norte do país. Ressalta a autora que a população negra do Ceará construiu expressões distintas e para a afirmação de suas práticas culturais, ações cujo objetivo foi a conquista de espaços e legitimação de direitos atualmente muito presentes no cotidiano da população afrodescendente cearense. 
Por outro lado, ao abordar o tema da presença da população negra no Ceará, Silva (2017) pontua que a expressão "terra da luz" foi utilizada para denominar o Ceará, tendo ganhado força durante o processo de abolição da escravatura, ocorrida oficialmente no dia 25 de março de 1884. O fato fomentou a ideia de que a capital Fortaleza e o Ceará como um todo, seria um exemplo a ser seguido na luta abolicionista. Tal conotação heroica atribuída à abolição dos escravizados foi decisiva para a consolidação de uma identidade regional vinculada à expressão "terra da luz".

Dentre os problemas da expressão "terra da luz" elencados por Silva (2017) estão o fato de que nenhuma referência foi feita à atuação dos libertos, ou seja, dos próprios negros escravizados, pois os créditos da luta pela abolição foram, via de regra, dados à elite cearense organizada em sociedades abolicionistas e ao fato de que ocorreu nos anos posteriores a produção da ideia de que os negros no Ceará eram poucos, quase não existiam. De uma maneira geral, a autora argumenta que a população negra teve sua história e cultura deixadas de fora da historiografia oficial regional no Ceará, que enfatizou a ideia de formação étnica da população cearense a partir da mistura de brancos e índios, em especial, a partir da figura do caboclo.

Ratts (1998) argumenta que a constituição de uma identidade regional para o Ceará, desde a segunda metade do século XIX, apoiou-se na afirmação de ausência da população negra na formação étnica dos cearenses. A falsa ideia de ausência dos negros foi criada por intelectuais que privilegiaram certas versões da história de indígenas e negros nessa porção do território nacional que se constituiu como o Estado do Ceará. No entanto, o autor pondera que durante a década de 1980, no Estado do Ceará, iniciou-se um processo de "descoberta" de agrupamentos negros. Também é nesse período histórico que ocorreu a constituição do movimento negro no Estado.

Ao retomar a construção dessa falsa ideia de ausência da população negra, Ratts (idem) demonstra que os historiadores tomaram a categoria negro como sinônimo de escravo, afirmando que essa mão de obra foi pouco utilizada no Ceará, concentrando-se nos serviços domésticos e nos poucos engenhos de rapadura. A essa formulação construiu-se também o argumento de que teria ocorrido nesse Estado uma "escravidão branda" caracterizada pelo contato íntimo entre o senhor e o escravizado.

Observa Ratts (1998) que a historiografia cearense também ressalta a abolição pioneira da escravidão. Ocorrida em 1884, tal historiografia concebe a abolição como resultante de uma conjunção de fatores, quais sejam, dessa suposta pequena utilização da mão de obra escravizada, da seca ocorrida em período imediatamente anterior e, por último, da ação de um movimento abolicionista no Ceará.

Seguindo os argumentos de Ratts (idem), ocorre que os indícios da presença negra no Estado do Ceará contradizem essa historiografia regional. O autor afirma que, ao contrário dessa tradição regional que reforça a ideia de ausência de população negra, há muitas referências, ainda que fragmentadas, de formação de mocambos, fugas, atos de torturas contra escravizados e atitudes de rebeldia. A presença de negros fugitivos vivendo em quilombos nos sítios nas periferias de Fortaleza e apresentações dos Reis Congos ligados às irmandades de homens pretos são referidos para todo o século XIX, assim como a existência de agrupamentos negros já no século XX, como os Bastiões.

De acordo com Santos Silva et al (2018), o estado do Ceará apresenta a existência de quilombos desde a sua formação no período colonial. Constituídos por africanos em busca de liberdade, em grande parte provenientes das fazendas do estado de Pernambuco, a produção de gado, couro e carne de sol estavam alicerçadas na mão de obra de africanos escravizados. Para os autores, não há como negar que as atividades vinculadas ao engenho de rapadura, algodão e mineração, navegação, transporte de mercadorias e construções urbanas também se realizaram com trabalho de escravizados, o que resultou na formação de inúmeras comunidades rurais e urbanas de população de africanos e descendentes.

Para Santos Silva et al (idem), a formação de quilombos no estado do Ceará não difere muito dos demais estados da região Nordeste. Algo característico, no entanto, diz respeito às atividades econômicas e número de escravizados empregados, uma vez que a concentração nas propriedades era menor, devido às atividades econômicas de menor amplitude condicionadas 
pelo clima e pelo solo. Os autores também destacam a migração de outros estados durante o período do escravismo e depois da abolição como um fator relevante para a constituição da população negra no Ceará, o que levou à formação de muitas comunidades negras rurais no estado do Ceará.

Apesar dessa presença, de acordo com Ratts (1998), é somente a partir da década de 1980 que foram iniciadas pesquisas a fim de revisar os estudos sobre a escravidão e a abolição no Ceará, que passam a enfatizar a presença negra e a mão de obra escravizada no sertão nordestino, utilizada principalmente nas atividades pecuárias. Com isso, é possível afirmar que a história dos negros no Estado do Ceará desempenhou um papel vital e ativo na formação étnica e na cultura da população geral. No mais, se tornou possível mapear uma série de concentrações de negros nas vilas e cidades maiores e mais antigas e irmandades de homens pretos e pardos onde passaram a ser identificados diversos agrupamentos negros.

Ratts (1998) afirma que o esforço científico iniciado na década de 1980, concomitante à constituição do movimento social no Estado, com toda certeza são marcos fundamentais na luta contra a tese da ausência do negro, e é nesse contexto que as comunidades negras rurais do Ceará iniciam suas pautas de reivindicação de direitos territoriais a partir da autoafirmação identitária. Silva (2017) informa que o Movimento Negro Cearense surgiu em 1982, com a criação da seção cearense do grupo de União e Consciência Negra, que levou à discussão e mobilização negra, especialmente das comunidades quilombolas no começo dos anos 1990. No entanto, o primeiro encontro de comunidades negras do Ceará ocorreu somente em 1998. Na figura abaixo podemos vislumbrar a presença das Comunidades Quilombolas no território cearense.

Figura 3 - Comunidades Quilombolas no Estado do Ceará.

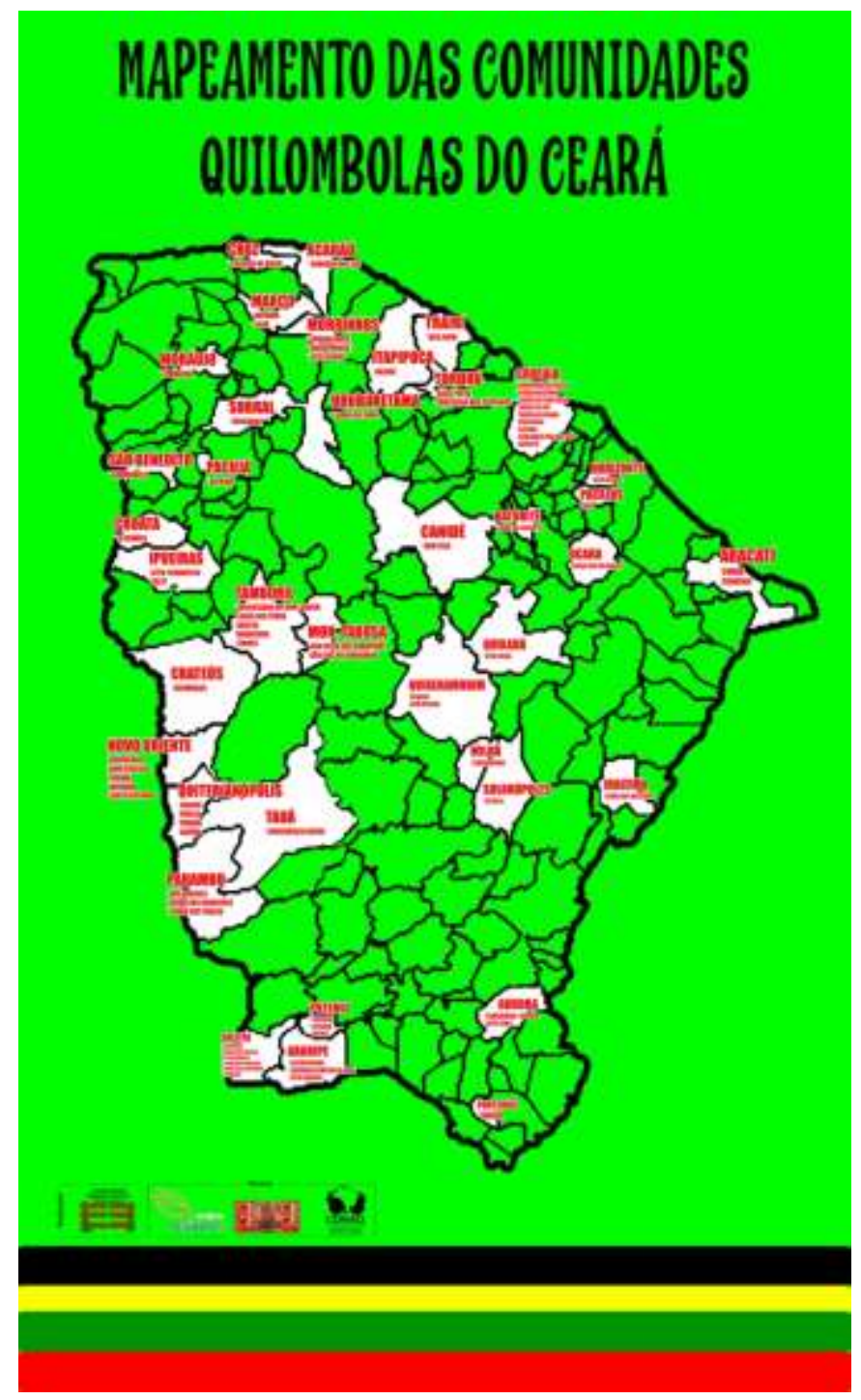


Fonte: Mapeamento iniciado em 2018 e finalizado em Março de 2019, Marisa Alencar et al. http://quilombodocumbe.blogspot.com/2019/12/mapa-das-comunidades-quilombolas-do.html?m=1

\subsubsection{Territórios quilombolas na Região do Cariri (CE)}

Neste subtópico tratamos de alguns aspectos relacionados ao processo de ocupação do território cearense com enfoque na região do Cariri. Compreende-se Cariri o conjunto de municípios localizados no interior do Ceará conforme figura a seguir. Nesse processo veremos que, conforme Tavares (2020), as migrações para a região do Cariri devem ser consideradas como um fator importante na formação e consolidação das comunidades quilombolas.

Figura 4 - Região do Cariri Cearense.

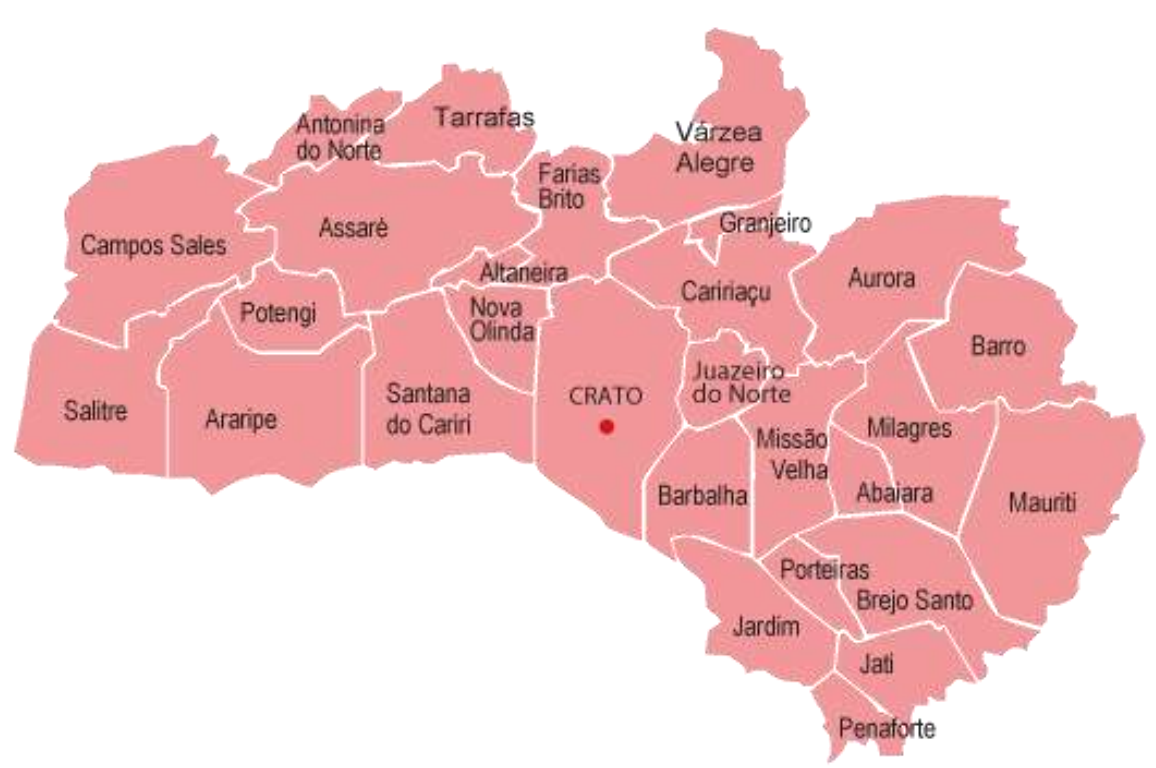

Fonte: http://sintsefceara.org.br/delegacias/cariri/

Tavares (2020) destaca o fenômeno religioso vinculado à cidade de Juazeiro do Norte, iniciado em 1989, em decorrência do evento conhecido como "milagre da hóstia", em que uma hóstia se transmutou em sangue na boca da Beata Mocinha. Tal feito atraiu milhares de pessoas sendo um marco histórico a partir do qual Juazeiro do Norte irá se consolidar como uma cidade-polo de atração de investimentos em decorrência também das romarias do Padre Cícero Romão Batista. Nesse ponto, informa o autor que o próprio padre Cícero exerceu papel importante no processo de fixação de alguns romeiros ao incentivá-los a iniciar pequenos negócios, como fábricas e comércios.

Com relação às famílias negras e indígenas que compunham o contingente de migrantes em busca de proteção e sustento, Tavares (2020) afirma que um beato por nome de José Lourenço, negro, reunia essas famílias em uma localidade chamada Caldeirão, em que o modo de vida coletiva se assemelhava a alguns princípios da organização social própria dos quilombos.

O importante a reter acerca do processo histórico de formação dos quilombos na região do Cariri, conforme argumenta Tavares (2020), é o contexto das migrações ocorridas, em especial devido à mão de obra para o trabalho nos engenhos de cana-de-açúcar e, também, os motivos religiosos. A esses fatores devem ser considerados os maus tratos praticados pelos dos donos das terras em outras localidades, as secas, as expulsões de trabalhadores e a falta de políticas para uma população dita livre, mas ainda escravizada pela subordinação aos donos das terras onde moravam. 
Seguindo os argumentos de Tavares (2020), o Cariri cearense também deve ser considerado como uma exceção na realidade geral do sertão nordestino, pois conta com temperatura relativamente amena, abundância de água na maior parte de seu território e foi impactada positivamente pelo crescimento do município de Juazeiro do Norte. Tais fatores tornaram a economia local mais diversificada e não restrita ao setor de subsistência, como ocorre em grande parte do interior do estado do Ceará.

Com relação aos deslocamentos para o trabalho nos engenhos de cana-de-açúcar do Cariri cearense, Tavares (idem) informa que essas migrações ocorreram durante a escravidão e também após a abolição dos escravizados, o que explica o grande contingente de população preta e parda na região, ao final do século XIX. O autor argumenta que as migrações provocadas pela necessidade de mão de obra nos engenhos precedem àquelas de ordem religiosa. Ocorre também que parte significativa dos romeiros migrados para o Cariri eram negros vindos, em especial, do estado de Pernambuco, Alagoas e Paraíba.

No início do século XX ocorreu na região do Cariri a expansão da criação de gado, o que provocou conflitos territoriais com a expulsão de muitas famílias de seus locais de ocupação. Desterritorializados, grupos familiares se deslocaram para regiões mais isoladas, o sertão do semiárido, as áreas mais elevadas da Chapada do Araripe. Nessa região, marcada pela dificuldade de acesso à água e baixa qualidade da terra, famílias pretas e pardas teriam encontrado refúgio ante à expansão pecuária em curso comprando porções de território de baixo valor (Tavares, 2020).

Conforme argumenta Tavares (2020), a origem das comunidades quilombolas na região do Cariri não foi diferente do restante do Brasil e vincula-se, principalmente, às injustiças sociais decorrentes da falta de acesso à terra. Por sua vez, o contexto de reivindicação por direitos, apesar de histórica, assume particular destaque ao final da década de 1980, com a garantia constitucional dos direitos territoriais.

De acordo com Tavares (2020), havia no Cariri cearense em 2019, 06 (seis) comunidades quilombolas com procedimentos de regularização fundiária em tramitação no Instituto Nacional de Colonização e Reforma Agrária (INCRA), e outras 06 (seis) com certificação pela Fundação Cultural Palmares. Para além desses processos em tramitação o autor afirma que em mapeamento realizado, também no ano de 2019, foram registradas 28 (vinte e oito) comunidades negras e quilombolas na região do Cariri cearense.

O importante a enfatizar acerca do processo de formação das comunidades quilombolas da região do Cariri é que sua população, em sua maioria, é formada por antigos moradores de fazendas de cana e de gado. A fim de se livrarem das péssimas condições de trabalho, essa população conseguiu adquirir outras áreas para estabelecerem moradia, formando assim os quilombos. É por isso que muitas famílias possuem título de pequenas propriedades ou ocupam pequenas áreas que, na maioria dos casos, são insuficientes para garantir plenas condições de vida (Tavares, 2020).

Outro dado importante sublinhado por Tavares (2020) é o fato de que no contexto de formação dos quilombos no Cariri os conflitos sempre estiverem presentes, pois a histórica exploração do trabalho escravo no passado tendeu a se perpetuar através da negação de direitos básicos e, principalmente, do controle e expulsão da população negra das melhores terras da região. Na próxima seção, analisaremos o processo de formação de uma comunidade quilombola específica, o Quilombo Arruda. Vejamos.

\subsubsection{Comunidade quilombola do Sítio Arruda}

Ao recuperar o contexto de formação da comunidade quilombola do Arruda, Tavares (2020) afirma que os antigos territórios ocupados pelas comunidades passaram a ser de interesse dos fazendeiros devido às suas condições propícias para a criação de gado e plantio de capim e cana-de-açúcar. Devido à pressão dessa expansão agropecuária, os grupos familiares tiveram que sair de suas antigas terras, estabelecendo-se em terras mais distantes, baratas e com escassez de água. Como 
veremos abaixo, algumas famílias quilombolas já eram proprietárias de uma pequena porção de terra e com o processo de certificação e regularização fundiária tiveram seus territórios ampliados.

A Comunidade Quilombola do Sítio Arruda localiza-se no município de Araripe (CE), conforme a figura 5, e sua população local descende de um grupo de famílias negras que trabalhavam para o coronel Ottoniel Barreto da Silva (Tavares, 2020). A história de ocupação dessa localidade envolve a compra da terra, há cerca de 40 (quarenta) anos atrás, feita com o dinheiro da venda de uma propriedade recebida de herança de um lugar chamado Sítio Coqueiro.

Figura 5 -Mapa de localização da Comunidade quilombola do Sítio Arruda em Araripe - CE.

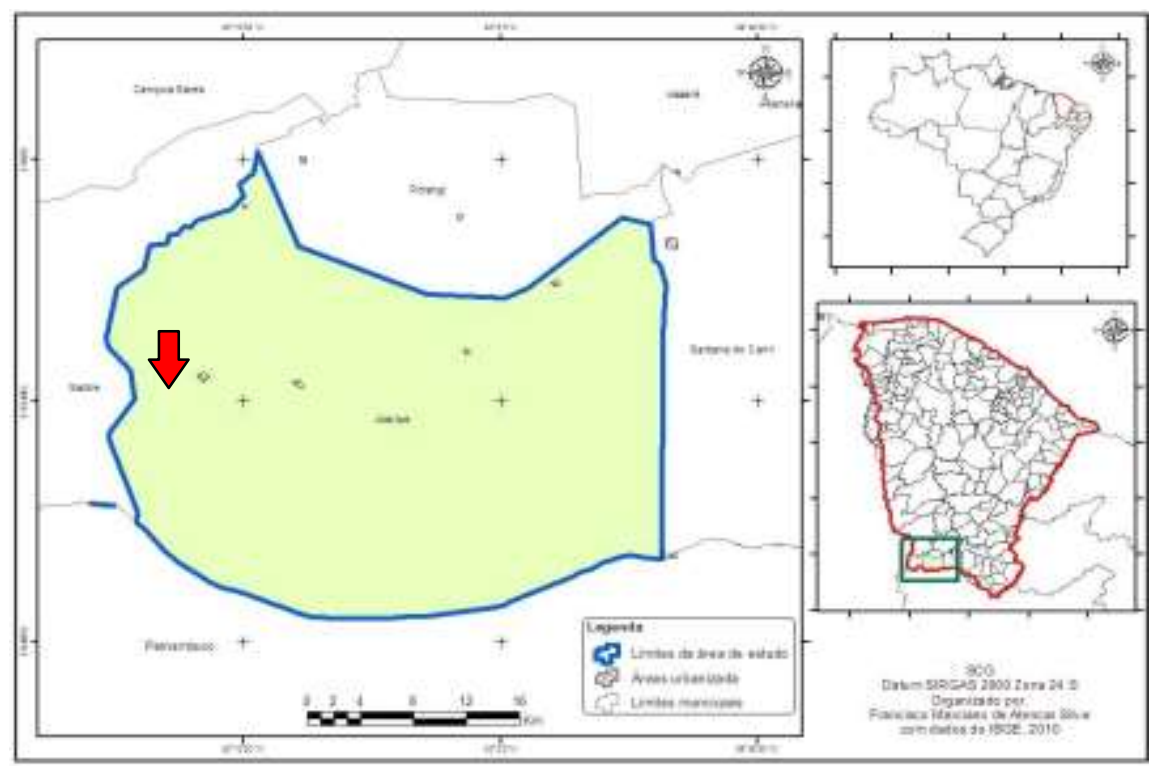

Fonte: Francisco Marciano de Alencar. Geografo, URCA. (2016).

Informa Tavares (2020) que a comunidade tradicional Quilombo Arruda se formou a partir de 3 (três) grupos familiares (Nascimento, Caetano e Pereira da Silva) descendentes de pessoas escravizadas originárias de regiões diferentes: Cabrobó (PE), Sertão dos Inhamuns (CE) e da própria Chapada do Araripe. O autor retoma que no momento da certificação pela Fundação Cultural Palmares, em 2009, ocorria na comunidade uma situação de exploração do trabalho, problemas fundiários e patriarcalismo. Tal contexto adverso impulsionou a articulação de diferentes agentes em um esforço de reparação de violação de direitos humanos que envolveu, especificamente, a autoidentificação da comunidade quilombola.

Após a certificação pela Fundação Cultural Palmares, foi iniciado o procedimento de regularização fundiária que, de acordo com Tavares (2020), tendo cumprido todas as fases, aguarda a emissão do título definitivo relativo a um território que conta com 333,34 hectares. A delimitação desse território contou com uma negociação junto aos proprietários de terra vizinhos, uma vez que a terra comprada inicialmente pelos moradores locais abrangia uma área bem menor. Em síntese, o procedimento de certificação quilombola e subsequente processo de regularização fundiária aumentou consideravelmente o território de direito da comunidade quilombola Sítio Arruda.

Tavares (2020) informa que, após o reconhecimento como quilombolas, os moradores mantiveram a expectativa por projetos e políticas assistenciais o que, na visão do autor, aumentou a dependência dos agentes estatais. Uma das principais expectativas não se realizou, qual seja, a que dizia respeito à perfuração de um poço artesiano na comunidade. Com isso, o acesso à água de qualidade continua sendo através do fornecimento do poder público local. Aqui é interessante ponderar se o que o autor considera como dependência de agentes estatais não se vincularia, na verdade, a uma estratégia em que, ao mobilizarem um reconhecimento identitário, visam aumentar seu poder político no pleito de políticas públicas. Nesse sentido, o 
ocorrido no Quilombo do Sítio Arruda tratar-se-ia mais de um uso político da identidade, no sentido forte do termo, do que uma passagem para a dependência.

Ao retomar o processo de reconhecimento da identidade quilombola a partir de entrevistas realizadas no local, Tavares (idem) recupera a importância da atuação de um vereador e técnico da Secretaria de Agricultura do município de Araripe, que indicou a comunidade para compor o Programa Um Milhão de Cisternas (P1MC). Tal inserção foi justificada devido à falta de acesso à água de qualidade recorrente na então comunidade rural. Tavares (2020) afirma que durante as capacitações do P1MC houve o processo de reconhecimento dos moradores como comunidade quilombola com o subsequente pedido de certificação à Fundação Cultural Palmares, ocorrido em 2009. O estatuto da associação comunitária foi alterado, que passou a ser chamada de Associação Quilombola do Sítio Arruda. Com a certificação, houve o acesso às políticas específicas de saúde, educação, assistência social e assistência agrícola e inclusão no Programa Luz para Todos.

Tavares (2020) também informa que durante o processo de reconhecimento do Sítio Arruda como comunidade quilombola houve a atuação de diferentes agentes na mobilização e educação para os Direitos Humanos, como os gestores públicos municipais, uma associação cristã de base, a Cáritas Diocesana do Crato e o Grupo de Valorização Negra do Cariri (GRUNEC). Pelo exposto, é possível argumentar mais uma vez que ao invés de dependência de agentes externos, como afirmado pelo autor, parece-nos ter ocorrido uma construção e articulação em rede de atores centrais na luta pelos direitos da população quilombola, articulação que foi exitosa no pleito da comunidade pela certificação de sua identidade e no subsequente processo de regularização fundiária.

De acordo com Tavares (2020), o número de famílias residentes na comunidade quilombola Sítio Arruda, à época da certificação pela Fundação Cultural Palmares, em 2009, que era um total de 34 (trinta e quatro), aumentou consideravelmente e contava, à época da pesquisa realizada pelo autor, com cerca de 50 (cinquenta) famílias. Algumas dessas famílias efetivaram um retorno de locais para onde tinham migrado em busca de trabalho. Também informa o autor que a escola da comunidade atende estudantes da região e não somente os estudantes quilombolas. Com relação à produção de alimentos, existem roças de feijão, mandioca e milho, principalmente. Apesar da existência de cisternas, a dificuldade no acesso à água é um imperativo conforme a Figura 6.

Figura 6 - Cisternas na Comunidade do Sítio Arruda.

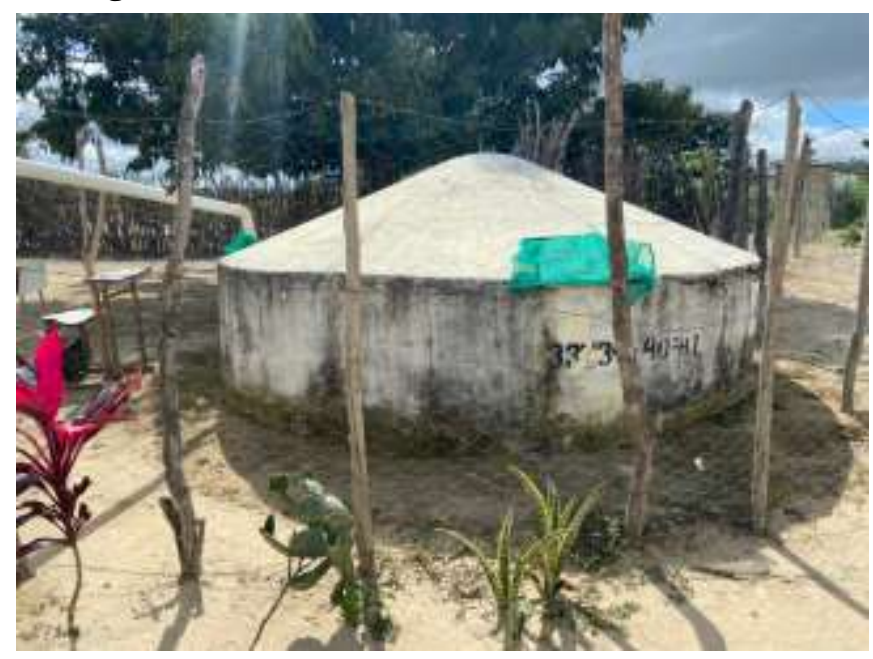

Fonte: Dados da pesquisa (2021).

Um elemento interessante observado por Tavares (2020) diz respeito ao abandono de certas práticas culturais herdadas dos antepassados, como algumas festas e danças. O autor argumenta que esse abandono é decorrente de um crescente preconceito transmitido, principalmente, via religiosidade católica tradicional. A questão religiosa assume destaque, pois houve 
um abandono das religiões de matriz africana, como a Umbanda e o Candomblé, e tem prevalecido uma religiosidade católica vinculada à crença, disseminada pela região Nordeste, de forma geral, em Frei Damião e Padre Cícero. No entanto, observa o autor que permanecem algumas práticas religiosas vinculadas à Umbanda e ao Candomblé, assim como a preservação de santos católicos misturados com os Orixás em alguns altares.

Ainda com relação às práticas culturais relacionadas à religiosidade, informa Tavares (2020) que a comunidade quilombola do Sítio Arruda se transformou em uma referência na organização da festa da padroeira da região e na comunidade há uma capela cuja padroeira é Nossa Senhora Aparecida. A presença de rezadeiras e de mezinheiras - mulheres especialistas no preparo de ervas medicinais para tratamento de doenças - é intensa, assim como há na comunidade grupos de mulheres que cantam os benditos (orações).

Tavares (2020) argumenta que na comunidade quilombola Sítio Arruda há uma prevalência da identidade de trabalhadores rurais e que existe na comunidade uma identidade quilombola diferenciada que não se articula no contexto do movimento quilombola estadual. No entanto, a comunidade quilombola do Sítio Arruda representa uma força política na região do Cariri Oeste. Em síntese, a participação política da comunidade é mais localizada e se debruça sobre a luta por direitos e planejamento de políticas públicas.

Faz-se necessária uma ponderação quanto à afirmação de Tavares (2020) sobre a proeminência da identidade de trabalhadores rurais entre os quilombolas do Sítio Arruda, qual seja, que a categoria trabalhadores rurais se vincula mais a uma categoria social do que identitária. Nesse sentido, parece-nos ocorrer uma imprecisão por parte do autor ao discorrer sobre o tema, pois o vínculo com a terra não deveria ser tratado como uma característica de perda da identidade quilombola porque, nesse caso, e ao que tudo indica, a construção da identidade quilombola envolve justamente as práticas agrícolas e demais formas de manejo do território em questão - expressões, no limite, de um saber fazer propriamente quilombola.

Ainda com relação à análise feita por Tavares (2020), o autor afirma que os quilombolas do Arruda não preservaram a maioria de suas atividades culturais e expressões religiosas da identidade negra quilombola. Nesse ponto, parece-nos que o autor possui uma compreensão apriorística do que deve ser considerado como identidade quilombola. Ou seja, atrela o conceito complexo de identidade quilombola as pressupostas manifestações culturais como se para ser quilombola fosse necessário possuí-las. Ao invés de operar com o idioma da "perda cultural”, o autor poderia adotar uma compreensão que levasse em conta as transformações socioculturais ocorridas no Quilombo do Arruda, afastando-se, dessa forma, de compreensões exotizantes acerca do que condiciona como "cultura quilombola" e mais próxima da realidade local vivida.

Mais de uma vez Tavares (2020) reitera o vínculo dos moradores do Quilombo Arruda com o trabalho agrícola indicando tanto a produção local como o fato de serem requisitados pelos fazendeiros locais para atividades agropastoris sazonais. O autor identifica a produção do Tijolo de Barro Cru com uma prática herdada dos antepassados, assim como o trabalho em mutirão conforme a Figura 7. Ao que nos parece, tais elementos, em seu conjunto, conformam a identidade quilombola do Sítio Arruda. 
Figura 7 - Produção de tijolos artesanais no Sítio Arruda.

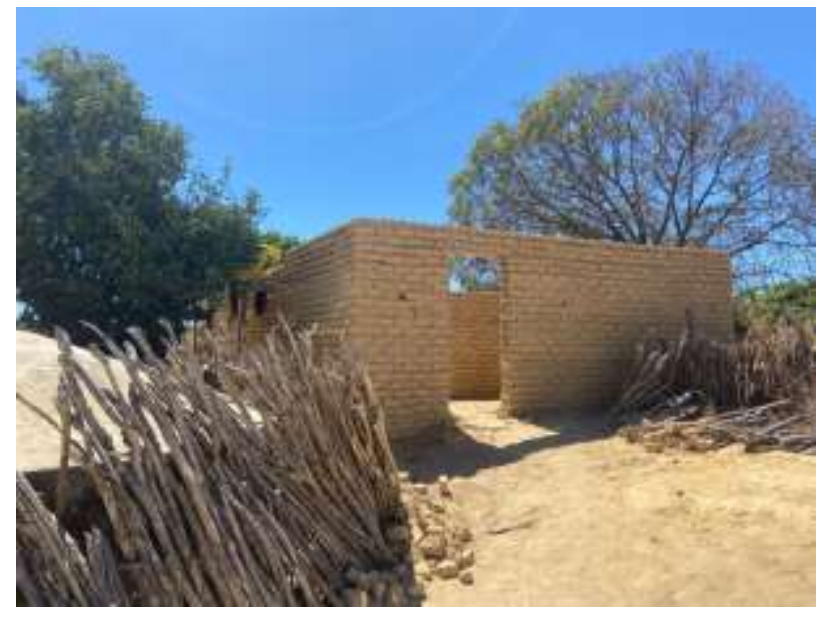

Fonte: Dados da pesquisa (2021).

Cabe retomar aqui o princípio da autodefinição ou auto-identificação como norteador principal da identidade dos povos e comunidades tradicionais (OIT, 1989), ou seja, é a consciência de pertencimento a uma identidade o que atesta o pertencimento de um grupo a uma determinada cultura. Da consciência identitária deriva o direito à autodeterminação (OIT, 1989), que diz respeito ao direito de um grupo fazer escolhas com relação ao seu projeto de vida. Por tudo isso, ser quilombola corresponde muito mais a um direito e a uma consciência identitária do que ao cumprimento de expectativas exteriores enraizadas em pressupostos exotizantes do que deve ser uma determinada cultura.

Ao tratar da centralidade da terra para os moradores da comunidade quilombola Sítio Arruda, Silva (2017) elabora uma abordagem diametralmente oposta à de Tavares (2020). Silva (idem) argumenta que a conquista territorial se vincula a um aspecto fundamental da identidade local. Nesse sentido, o plantio e a garantia do sustento familiar conformam a relação afetiva dos moradores com a terra. A terra constitui-se também como um elemento imprescindível para o exercício da cidadania, do pertencimento e manutenção das afinidades familiares e sociais.

Silva (2017) argumenta que a terra se tornou tema central nas lutas dos povos afro-brasileiros em decorrência do histórico processo de expropriação levado a cabo durante o período escravagista brasileiro e também após a abolição e na contemporaneidade. Ou seja, trata-se de um direito historicamente negado. A partir dessa constatação, é muito relevante a conquista dos moradores da comunidade quilombola Sítio Arruda, pois conseguiram expandir seu território significativamente. Tratou-se, portanto, de uma conquista que permitiu a própria permanência na comunidade de famílias que já haviam migrado para outras localidades.

Conforme demonstra Silva (2017), o direito de uso da terra no Sítio Arruda é um direito coletivo assegurado a todos os que são considerados e se consideram membros da comunidade. Isso é, um direito extensivo aos que se enquadram nos critérios de pertencimento ao grupo - critérios esses referentes aos vínculos por parentesco consanguíneo e/ou por afinidade. Em síntese, os critérios de pertencimento na comunidade quilombola Sítio Arruda estão estritamente relacionados com a terra, por isso, os laços de identificação estão estreitamente ligados aos lugares.

Cabe-nos, por fim, argumentar que a compreensão acerca da identidade local na comunidade quilombola Sítio Arruda parece vincular-se ao imprescindível dimensionamento da relação de seus moradores com a terra e, por conseguinte, com a conquista territorial pela comunidade. Nesse sentido, a garantia aos direitos territoriais assume notória relevância e encontra-se em algum lugar para além das formalidades jurídicas, tratando-se, de fato, de um elemento substancial que fomenta as relações 
sociais construídas e mantidas no local. Por tudo isso, o atual cenário de retrocessos com relação à garantia dos direitos constitucionais das comunidades quilombolas deve ser efetivamente denunciado e discutido.

\section{Considerações Finais}

A proposta deste trabalho foi a de atentar para o atual cenário de retrocessos na garantia dos direitos constitucionais das Comunidades Quilombolas no Brasil. A partir dessa justificativa, propomos discutir o conceito de quilombo sob uma perspectiva sócio-histórica tendo como metodologia uma revisão bibliográfica sobre o tema. Por tratar-se de um tema abrangente, foi necessário realizar uma delimitação do tema elegendo uma estrutura de análise que tratou de maneira panorâmica desde a constituição em território africano da instituição kilombo (quilombo) (Nascimento, 2018 [1985]) até sua inserção na realidade brasileira (Nascimento, idem; Marques e Gomes, 2013; Moura, 2021; Querino, 2018). Foi dado enfoque ao estado do Ceará (Ratts, 1998, 2016; Silva, 2017; Santos Silva et al, 2018) e, mais especificamente, para a região do Cariri cearense (Santos, 2018; Silva, 2017; Tavares, 2020), abordando uma comunidade quilombola específica, o Sítio Arruda.

Concluímos que o conceito de quilombo passou por significativas mudanças desde sua constituição em território africano. Associado originalmente a uma instituição revolucionária angolana e inserido na história da pré-diáspora, no Brasil o quilombo tornou-se um código de reação ao colonialismo cultural ao reafirmar a herança africana e buscar um modelo brasileiro de fortalecimento da identidade étnica (Nascimento, 2018 [1985]). No mais, também vimos que embora o aquilombamento não tivesse um novo projeto de ordenação social com capacidade para substituir o escravismo, por outro lado, havia potencial e dinamismo suficientes para provocar permanentes crises em sua estrutura (Moura, 2021).

O termo quilombo conforma um campo conceitual que possui uma longa história. Na contemporaneidade, o conceito de quilombo remete à associação de grupos em organizações sociais, religiosas e políticas em busca do autorreconhecimento como um grupo específico que busca pelo direito à sua territorialidade. Nesses grupos, evidenciam-se as relações com o passado escravista, a existência de rituais ou religiosidades compartilhadas, a origem ou ancestrais em comum, as relações de parentesco generalizado e, sobretudo e de uma maneira central, uma ligação profunda com o seu território.

Com relação à população negra no Estado do Ceará, frente a uma histórica invisibilidade reforçada pela falsa ideia de ausência dessa população, a chamada "Terra da Luz" tem, felizmente, sido cada vez mais evidenciada por inúmeros pontos negros. Evidencia-se, dessa forma, um processo de emancipação política em que mãos e vozes emergentes re-escrevem e recontam a história em seus próprios termos.

É fundamental que ocorra uma descolonização do conhecimento que, nos termos da autora, passa necessariamente por uma africanização do currículo e utilização das pedagogias propriamente quilombolas para a transmissão do conhecimento. Por certo, há ainda um caminho longo a ser percorrido. Nesse sentido, é importante enfatizar que, de acordo com Ratts (2016), especificamente a região do Cariri cearense é uma área de concentração negra com antigos engenhos, canaviais e presença atual de reisados, quilombos, grupos do movimento negro e terreiros de religiões de matriz africana.

Interessante e também preocupante é refletir sobre o cenário atual, cuja imagem remete-nos a uma grande encruzilhada. Pois, se por um lado temos consideráveis avanços e resistências históricas em curso, por outro, há um caminho temeroso de retrocessos que se apresenta. No último dia de maio de 2021, por exemplo, houve uma revogação de uma competência atribuída à Fundação Cultural Palmares da Instrução Normativa no que diz respeito aos procedimentos administrativos a serem observados nos processos de licenciamento de obras, atividades ou empreendimentos que impactem comunidades quilombolas (Brasil, 2021). Trata-se, em síntese, de um grave retrocesso com relação à histórica atuação da Fundação Cultural Palmares na garantia dos direitos territoriais das comunidades quilombolas no Brasil, retrocesso esse alinhado à atual política do poder executivo, onde se observa uma intenção de impor aos povos e comunidades tradicionais uma política sem resistência, eis que é urgente a necessidade de aquilombar-se. 


\section{Referências}

Brasil (1988). Constituição da República Federativa do Brasil. Brasília, DF: Senado Federal: Centro Gráfico. https://www2.senado.leg.br/bdsf/bitstream/handle/id/518231/CF88_Livro_EC91_2016.pdf.

Brasil (2003). Decreto $n^{\circ} 4.887$, de 20 de novembro de 2003. Regulamenta o procedimento para identificação, reconhecimento, delimitação, demarcação e titulação das terras ocupadas por remanescentes das comunidades dos quilombos de que trata o art. 68 do Ato das Disposições Constitucionais Transitórias. http://www.planalto.gov.br/ccivil_03/decreto/2003/d4887.htm.

Brasil (2021). Ministério do Turismo, Fundação Cultural Palmares. Portaria $N^{o}$ 118. Revoga a Instrução Normativa No 1. https://www.in.gov.br/web/dou//portaria-n-118-de-31-de-maio-de-2021-323289079.

Corrêa, G. S. et al. (2020). A questão quilombola na conjuntura atual: Conflitos, desafios e r-existências. Revista da ANPEGE, 16, (29), 249 - 284. https://ojs.ufgd.edu.br/index.php/anpege/article/view/12509.

Cunha Júnior, H. 2013. Afrodescendência e Africanidades: Um dentre os diversos enfoques possíveis sobre a população negra no Brasil. Interfaces de Saberes, 1, 14-24.

Gil, A. C. (2017). Como elaborar projetos de pesquisa. 4.ed. São Paulo: Atlas.

Marques, C. E. E.; \& Gomes, L. (2013). A Constituição de 1988 e a ressignificação dos quilombos contemporâneos: limites e potencialidades. Revista Brasileira de Ciências Sociais, 28, (81).

Moura, C. (2021). Quilombos: resistência ao escravismo. (5a ed.). Teresina: EdUESPI.

Moura, C. (1981). Os quilombos e a rebelião negra. (1ª ed.). São Paulo: Brasiliense.

Nascimento, M. B. (2018) [1985]. O conceito de quilombo e a resistência cultural negra. 1985. In: Beatriz. Nascimento, Quilombola e Intelectual: Possibilidades nos dias da destruição. Maria Beatriz Nascimento. Diáspora Africana: Editora filhos da África.

Organização Internacional do Trabalho [OIT]. (1989). Convenção sobre Povos Indígenas e Tribais em Países Independentes [Convenção 169]. 27 jun. 1989. https://www.oas.org/dil/port/1989\%20Conven\%C3\%A7\%C3\%A3o\%20sobre\%20Povos\%20Ind\%C3\%ADgenas\%20e\%20Tribais\%20Conven\%C3\%A7\%C3 $\%$ A3o\%20OIT\%20n\%20\%C2\%BA\%20169.pdf.

Querino, M. (2018). O colono preto como fator da civilização brasileira. Coleção Acervo Brasileiro. (2a ed.). Jundiaí: Cadernos do Mundo Inteiro.

Ratts, A. (1998). Os povos invisíveis: territórios negros e indígenas no Ceará. Cadernos CERU, 9, 109-127. https://doi.org/10.11606/issn.25952536.v9i0p109-127.

Ratts, A. (2011). O negro no Ceará (ou o Ceará negro). Artefatos da cultura negra no Ceará. Fortaleza: Edições UFC, 19-40.

Ratts, A. (2016). A diferença negra e indígena no território: observações acerca de Fortaleza e do Ceará. GEOSABERES, Revista de Estudos Geoeducacionais, 7, (12), 3-16, Universidade Federal do Ceará. https://doi.org/10.26895/geosaberes.v.7i12.527.

Santos, A. P. (2018). Educação Escolar Quilombola no Cariri Cearense: Africanização da Escola a partir de Pedagogias de Quilombo. Dissertação de Mestrado, Universidade Federal do Ceará, Fortaleza, http://www.repositorio.ufc.br/handle/riufc/33415.

Santos, A. P.; \& Junior, H. A. C. (2019). Experiência educativa em comunidade quilombola Caririense: pedagogia de quilombo. Debates em Educação, 11, (23), 583-597.

Silva, M. E. (2017). História, memória e identidade quilombola no Cariri-cearense (Comunidades Sítio Arruda - Araripe e Carcará-Potengi. Dissertação de Mestrado, Universidade Federal da Paraíba, João Pessoa, PB, Brasil. https://repositorio.ufpb.br/jspui/handle/123456789/11901?locale=pt_BR.

Silva, S. P. S.; Santos, M. P.; C. J., Henrique; Bié, E. F.; \& Silva, M. S. (Orgs). (2018). Afroceará Quilombola. Porto Alegre: Fi.

Tavares, G. O. (2020). Territorialidades e identidades Quilombolas em questão na Chapada do Araripe - Cariri, Ceará. Tese de Doutorado, Universidade de Brasília, Brasilia, DF, Brasil. https://repositorio.unb.br/handle/10482/40432. 